\title{
Spar caves as fossil hydrothermal systems: Timing and origin of ore deposits in the Delaware Basin and Guadalupe Mountains, New Mexico and Texas, USA
}

\author{
David D. Decker*, Victor J. Polyak, and Yemane Asmerom \\ ${ }^{1}$ Radiogenic Isotopes Laboratory, Department of Earth and Planetary Sciences, University of New Mexico, Albuquerque, NM 87131, USA
}

\begin{abstract}
Studies of sulfuric acid hypogene speleogenesis have contributed significantly to understanding the history of the Guadalupe Mountains of southeast New Mexico and west Texas for at least the past $12 \mathrm{Ma}$. A recently published hypothesis of supercritical $\mathrm{CO}_{2}$ spar cave genesis provides information that constrains the timing of the start of uplift to between 27 and $16 \mathrm{Ma}$, and helps to explain landscape evolution of this region for the last $185 \mathrm{Ma}$. This new speleogenetic model is summarized here and shows that $\mathrm{U}-\mathrm{Pb}$ dating of crystals from different spar caves reveal different ages, and that a majority of the spar crystals were deposited during ignimbrite flare-up episodes at the end of the Basin and Range extension and onset of Rio Grande Rift extension between 36-28 Ma. During cave spar formation, geothermal gradients ranged from 50 to $70^{\circ} \mathrm{C} / \mathrm{km}$. Stable isotope data for $\delta^{13} \mathrm{C}, \delta^{18} \mathrm{O}$, and $\delta^{88} \mathrm{Sr}$ support that parent waters of cave spar were of low hydrothermal origin and mixed with gases emanating from shallow magma conduits; nearby outcrops of Tertiary igneous dikes of the same age as the spar support this hypothesis. Supercritical $\mathrm{CO}_{2}$ hydrothermal systems driven by magma intrusion on the western fringe of the Delaware Basin were responsible for the formation of small caves containing large, euhedral calcite crystals. Hydrothermal deposits from these types of systems are sometimes used to locate economic ore deposits, however, since this area has been uplifted, any indication of fossil hydrothermal systems, like travertine deposits, have eroded. Spar caves are remnants of hydrothermal processes and are related to and coeval with ore deposition and hydrocarbon generation in the Guadalupe Mountains and Delaware basin. These spar caves can be used as both proxies for landform evolution and to locate economic mineral deposits.
\end{abstract}

Keywords: $\quad$ hypogene speleogenesis, Guadalupe Mountains, ore deposit geology, petroleum maturation Received 7 January 2018; Revised 18 April 2018; Accepted 24 April 2018

Citation: Decker D.D., Polyak V.J. and Asmerom Y., 2018. Spar caves as fossil hydrothermal systems: Timing and origin of ore deposits in the Delaware Basin and Guadalupe Mountains, New Mexico and Texas, USA. International Journal of Speleology, 47 (3), 263-270. Tampa, FL (USA) ISSN 0392-6672 https://doi.org/10.5038/1827-806X.47.3.2173

\section{INTRODUCTION}

The Guadalupe Mountains are located at the boundary of three significant Cenozoic tectonic terranes: (1) the northern culmination of the Basin and Range province, (2) the southeastern margin of the Rio Grande Rift, and (3) the southeastern extreme of the structures formed during the Laramide Orogeny (Fig. 1) and is well studied, but little is known about the landscape evolution of the area and contradictory reports abound (King, 1948; Hayes, 1964; Meyer, 1966; Jagnow, 1977; Austin, 1978; Barker et al., 1979; Davis, 1980; McKnight, 1986; Hill, 1987, 1990, 1996; Garber et al., 1989; Mruk, 1989; Polyak, 1992; DuChene \& Martinez, 2000; Palmer \& Palmer, 2000; DuChene \& Cunningham, 2006; Kirkland, 2014).
King (1948) states that the landscape was of "postCretaceous age (after $65 \mathrm{Ma}$ ), most probably Oligocene to Miocene (28 to $20 \mathrm{Ma}$ )" and may have experienced up to three periods of uplift. Hills (1984) and McKnight (1986) suggest that there has been little to no uplift in the region since the end of the Permian ( 254 Ma) when the main cave forming strata of the Capitan Reef, the Capitan Limestone and the Artesia Group, were deposited. Eaton (1986) concluded that the area was uplifted during the formation of the Basin and Range ( $30 \mathrm{Ma})$ producing a topographic high to the west called the Alvarado Ridge, which subsequently subsided along a central basin during opening of the Rio Grande Rift (after $28 \mathrm{Ma}$ ). Lundberg et al. (2000) obtained a $\mathrm{U}-\mathrm{Pb}$ date of $90.7 \pm 2.8 \mathrm{Ma}$ from a cave spar sample from Big Canyon in the Guadalupe Mountains 


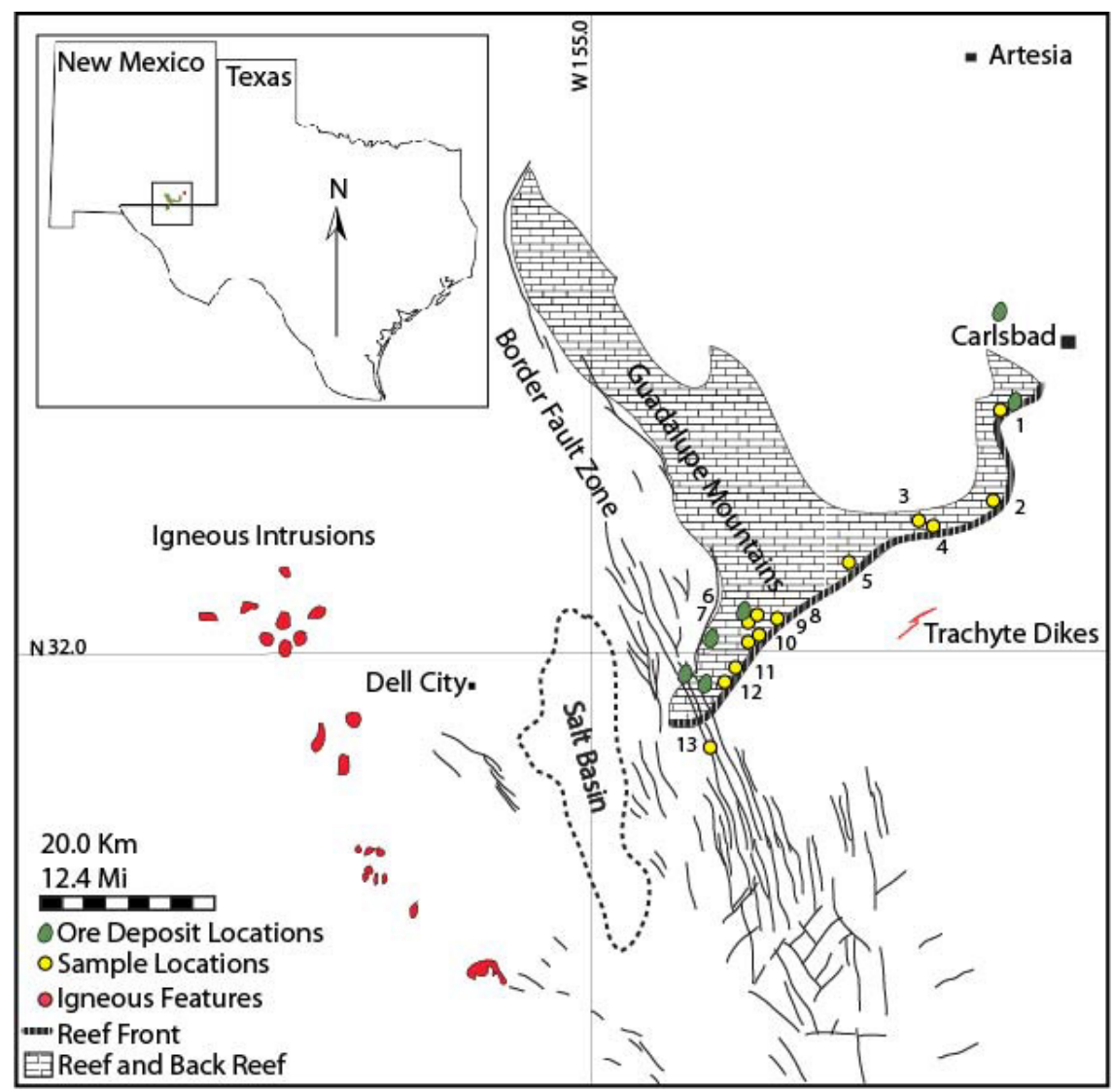

Fig. 1. Guadalupe Mountains of southeastern New Mexico and West Texas. This figure shows known fault zones, ore deposits, igneous intrusions, and spar collection locations. Compiled from Barnes (1983) and other sources including Google Earth.

and concluded that a deep seated hydrothermal event during the Laramide (90 - $50 \mathrm{Ma})$ produced the spar crystal and caused hydrocarbon maturation; and may have been responsible for post-Permian uplift of the region. Duchene and Martinez (2000) and Duchene et al. (2017) believe the Alvarado Ridge began to rise during the late Laramide based on paleobotanical evidence from the southern Rocky Mountains provided by Gregory \& Chase (1992). The landscape evolution of this region may seem simple, but based on the wide range of views the issue is not settled and is more complex than expected. Since there are few outcrops related to landscape evolution and ore generation, it becomes even more difficult to determine the absolute timing of the history of the Guadalupe Mountains. Finding a proxy for these processes would be valuable.

Spar caves in the Guadalupe Mountains are essentially large geodes lined with crusts of macrocrystalline calcite that formed long before the wellknown sulfuric acid speleogenetic events described by Hill (1996). Large scalenohedral calcite crystals are called 'cave spar' in this paper, and are phreatically precipitated (Gary et al., 2002). Cave spar growth in these spar caves as well as other large euhedral calcite spar of the Guadalupe Mountains and adjacent Delaware Basin (Fig. 2) has been described by Mruk (1985), Hill (1996), and Lloyd et al. (2013). Euhedral thermal spar used in this study fits the definition of spar II of Mruk (1985) and the mesogenetic spar of Hill (1996). The first dated spar crystal was older than Basin and Range (Lundberg et al., 2000), and Decker et al. (2018) reported multiple generations of spar that formed well before, during, and after Basin and Range development. Decker et al. (2016) determined that spar caves formed in the deep phreatic zone, a model that derived from the direct measurement of depth of three cave spar samples beneath known paleo-surface elevations relative to the spar caves. Two of the paleosurfaces were from paleo-water table elevations in the Guadalupe Mountains as determined by Polyak et al. (1998). The third measurement is from northern Arizona and measures the depth of a Grand Canyon paleo-surface to an underlying spar cave (Decker et al., 2016, 2018).

Because of the large spread in ages of the spar, finding an explanation for the origin of these spar caves and associated spar that accounts for these

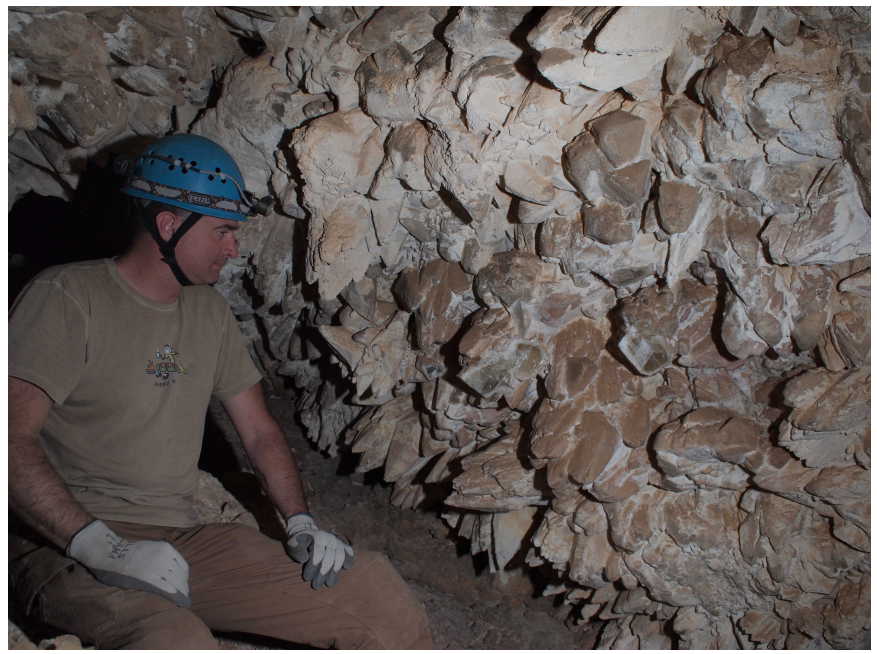

Fig. 2. Large spar cave truncated by sulfuric acid speleogenesis. These spar crystals range in size from $2 \mathrm{~cm}$ to $20 \mathrm{~cm}$ along the c-axis Cave near Carlsbad Caverns, NM. (Photo: Shawn Thomas). 
disparate ages has been problematic. Decker et al. $(2016,2018)$ proposed that spar caves and the associated cave spar were formed by supercritical $\mathrm{CO}_{2}$ $\left(\mathrm{scCO}_{2}\right)$ hypogene speleogenesis at a depth of $500 \pm$ $250 \mathrm{~m}$. U-Pb ages of cave spar show that most spar formed coeval with the ignimbrite flare-up and that there are at least five other generations of cave spar in the Guadalupe Mountains that are temporally linked to magmatic events. Supercritical $\mathrm{CO}_{2}$ hypogene speleogenesis explains both the origin of the caves and the associated spar as one speleogenetic event, coeval with magmatic activity.

The relative importance and absolute timing of each of these tectonic/magmatic events in the evolution of regional landforms is poorly known because of the lack of dateable materials in the Guadalupe Mountains and Delaware Basin. An advantage of studying a location at the boundary of these terranes is that tectonic events extend back before the Laramide Orogeny and provide multiple fluid-flow pathways from regionally distant areas. As long as the landscape does not sink or rise out of the 'spar horizon', that depth where supercritical $\mathrm{CO}_{2}$ transforms to aqueous $\mathrm{CO}_{2}$, spar cave speleogenesis will take place coeval with magmatic events, both nearby and from more distant locations. The calcite cave spar with warm fluid inclusion temperatures provides direct evidence for low temperature hydrothermal involvement (Decker et al., 2018). For the Guadalupe Mountains and Delaware Basin, spar caves and cave spar formed during the last $185 \mathrm{Ma}$ (Decker et al., 2018). This paper applies $\mathrm{scCO}_{2}$ spar cave hypogene speleogenesis to fossil hydrothermal systems linked to magmatic or thermal events that could be responsible for the origin of ore deposits and the maturation of hydrocarbons in the Guadalupe Mountains and Delaware Basin.

\section{BACKGROUND}

Details of $\mathrm{U}-\mathrm{Pb}$ and $\mathrm{U}$-series dating and stable isotope analyses methods are previously described by Decker et al. (2016, 2018). Calcite cave spar samples were collected from 16 caves along the length of the Guadalupe Mountains, and include a sample of mammillary calcite from Lake of the Clouds in Carlsbad Cavern, and a sample of fault-filling vein calcite from the Border fault zone on the southeastern side of the Guadalupe Mountains (site 13 of Fig. 1). Evidence for hydrothermal origin of cave spar comes from analysis of fluid inclusions and carbon and oxygen stable isotope values reported in Decker et al. (2018).

Each sample was selected based on lack of visual surface alteration (Figs. 2 and 3). Visible surface alteration is generally a sign that the crystal surface had been re-dissolved during subsequent speleogenetic episodes, most likely during the late stage $\mathrm{H}_{2} \mathrm{SO}_{4}$ speleogenesis, or that a hydration rim developed over time. The majority of samples were previously broken and the interior of the samples could be examined for evidence of alteration. All samples collected are mesogenetic spar that formed after the reef stopped growing and before the beginning of the $\mathrm{H}_{2} \mathrm{SO}_{4}$ speleogenetic event described by Hill (1996). A typical spar cave is 10 to 20 meters in diameter, and entirely lined with scalenohedral spar. These geode-like caves are as small as $10 \mathrm{~cm}$ in diameter and as large as 50 meters long by 30 meters wide and 10 meters tall. Crystals range from 2 to $3 \mathrm{~cm}$ long in small caves to as large as 2 meters in length along the c-axis in other Guadalupe Mountains caves (Figs. 2 and 3).

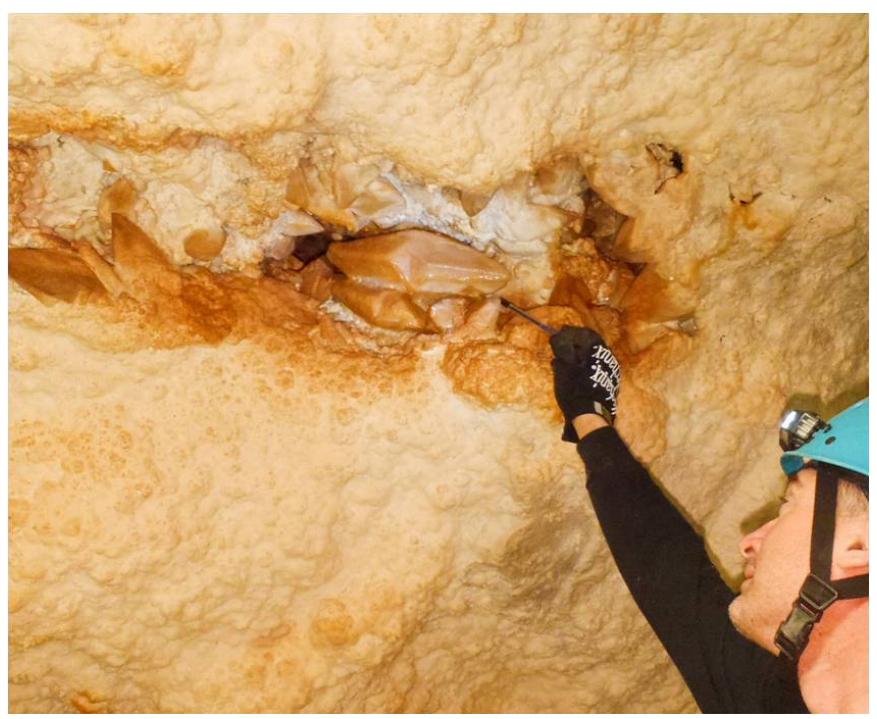

Fig. 3. In situ scalenohedral spar crystal in small ceiling vug (Photo: Jason Waltz).

Decker et al. (2018) reported U-Pb ages of cave spar calcite from 22 locations (16 caves, Fig. 1) that are clustered between 75 to $54 \mathrm{Ma}, 40$ to $34 \mathrm{Ma}$, and 30 to $28 \mathrm{Ma}$ (Fig. 4). Two of the samples formed prior to Laramide time: 184 and 118 Ma (Decker et al., 2018) and two spar samples were deposited post-Basin and Range time: $9.23 \pm 0.36$ and $13.1 \pm 0.3 \mathrm{Ma}$ (Decker et al., 2018). Fibrous fault filling spar from the Border Fault zone in Guadalupe Pass, Texas yielded an isochron age of $16.1 \pm 0.4 \mathrm{Ma}$, and constrains the timing of block faulting along the Border Fault Zone. The cave mammillary from Lake of the Clouds in Carlsbad Cavern, the deepest known point in the cave, was dated at $1.95 \pm 0.2 \mathrm{Ma}$. This places the water table well below the majority of the spar locations by the late Pliocene (after $5 \mathrm{Ma}$ ).

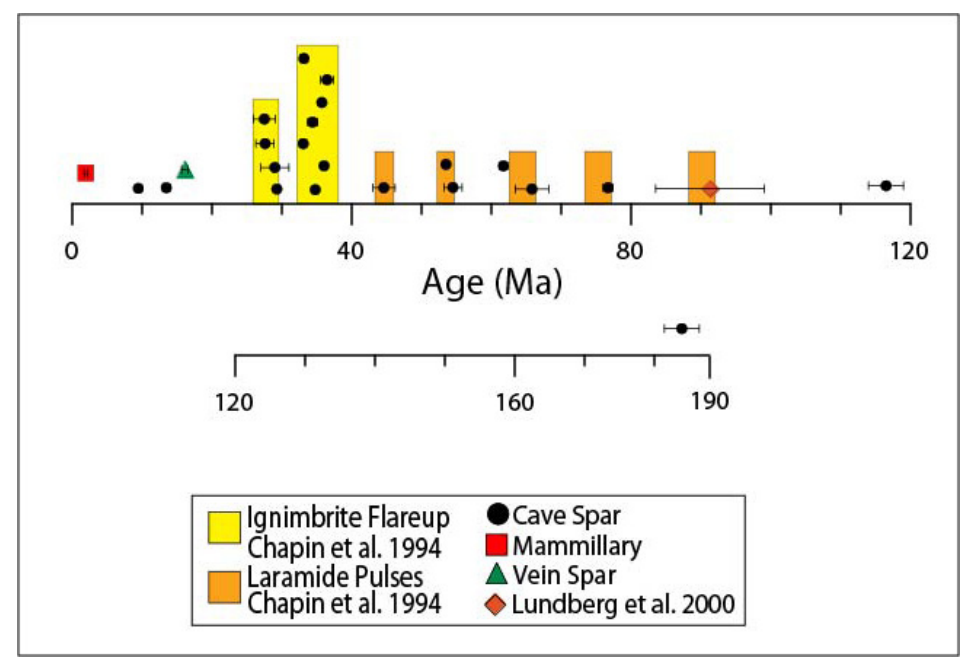

Fig. 4. Age data for spar crystals. Orange and yellow bars are times of known magmatic activity in the region. Figure modified from Decker et al. (2018). Vertical spread is only for visualization. 
Critical to the support of the $\mathrm{scCO}_{2}$ hypogene speleogenesis model is the depth of formation of three cave spar samples. The methodology for determining the depth at which these caves formed is described in detail in Decker et al. (2018). All three depths were in the range of $500 \pm 250 \mathrm{~m}$. A sample from the Grand Canyon yielded a $\mathrm{U}-\mathrm{Pb}$ age of $232 \pm 2 \mathrm{Ma}$. The cave this sample was collected in the Redwall Limestone and is located $\sim 750 \mathrm{~m}$ below Triassic-aged, near-sealevel sediments. From this, we infer that the Grand Canyon cave spar formed $\sim 750$ m below a paleo-water table (Decker et al., 2018). In Carlsbad Cavern sample CAVE-02399-003 yielded an age of $13.1 \pm 0.3 \mathrm{Ma}$, the elevation of CAVE-02399-003 is $~ 800 \mathrm{~m}$ below the elevation of the 13 Ma paleo-water table. CAVE-02399008 yielded an age of $9.23 \pm 0.36 \mathrm{Ma}$ and the elevation of this sample location is $400 \mathrm{~m}$ below the elevation of the paleo-water table at $9 \mathrm{Ma}$; this paleo-water table is defined by Polyak et al. (1998). Dublyansky (1995, 2000) approached the depth of spar cave formation from an analytical and observational point of view and determined that spar caves form at depths of $1 \mathrm{~km}$ and the large scalenohedral spar form at shallower depths between 250 and 500 meters below the water table, consistent with our results. This depth of formation of spar caves predicted by Dublyansky (1995, 2000) and Spötl (2009) is also the depth of the supercritical/subcritical $\mathrm{CO}_{2}\left(\mathrm{subCO}_{2}\right)$ boundary where carbonate rocks are reported to dissolve (Decker et al., 2016, 2018). The change from $\mathrm{scCO}_{2}$ to subCO $\mathrm{C}_{2}$ causes gas to exsolve and escape the system, causing a shift from water that is under saturated in $\mathrm{CaCO}_{3}$ and aggressive to carbonate rocks, to slightly super-saturated in $\mathrm{CaCO}_{3}$ allowing precipitation of calcite. The termination of magmatic activity causes a shift from dissolution to precipitation. The depth of formation of these spar crystals is an absolute measure of depth that is coincident with the depth of the supercritical/subcritical $\mathrm{CO}_{2}$ boundary, which can be used to explain both the origin of spar caves and the deposition of cave spar. Spar caves and spar crystals formed at elevated temperatures coeval with magmatic events and provide a mechanism for calcite dissolution followed by calcite precipitation.

Temperatures derived from fluid inclusions (Decker et al., 2016, 2018), and from vitrinite reflectance data (Barker \& Pawlewicz, 1987), yield a maximum geothermal gradient for the region during the time of the magmatic events. These data show that spar was deposited in temperatures ranging from 40 to $80^{\circ} \mathrm{C}$ and possibly as high as $90^{\circ} \mathrm{C}$. While these temperatures are not considered to be geothermally hot, and the depths are not tectonically deep, they can provide us with insight into near surface processes, and suggest that the region experienced hydrothermal events coeval with spar cave speleogenesis at temperatures high enough to cause maturation of hydrocarbons.

\section{DISCUSSION}

Hydrothermal buoyancy-driven flow exists over thermal point sources such as upwelling magma creating advective heat flow (Ingebritsen et al., 2006; Fig. 5). Continental crust heat flow is roughly $60 \mathrm{~mW} / \mathrm{m}^{2}$ in Paleozoic sedimentary rocks (Pollack et al., 1993) and has a geothermal gradient in the range of 20 to $35^{\circ} \mathrm{C} / \mathrm{km}$. Most often variations from these ranges are due to shallow magma, groundwater flow, or both (Ingebritsen et al., 2006). Fluid flow near magma bodies is driven by thermal convection, fluid density changes, and volatiles $\left(\mathrm{CO}_{2}\right.$,water vapor, and other minor constituents). The route that the ascending fluid takes with respect to hypogene speleogenesis is determined by pressure gradients,

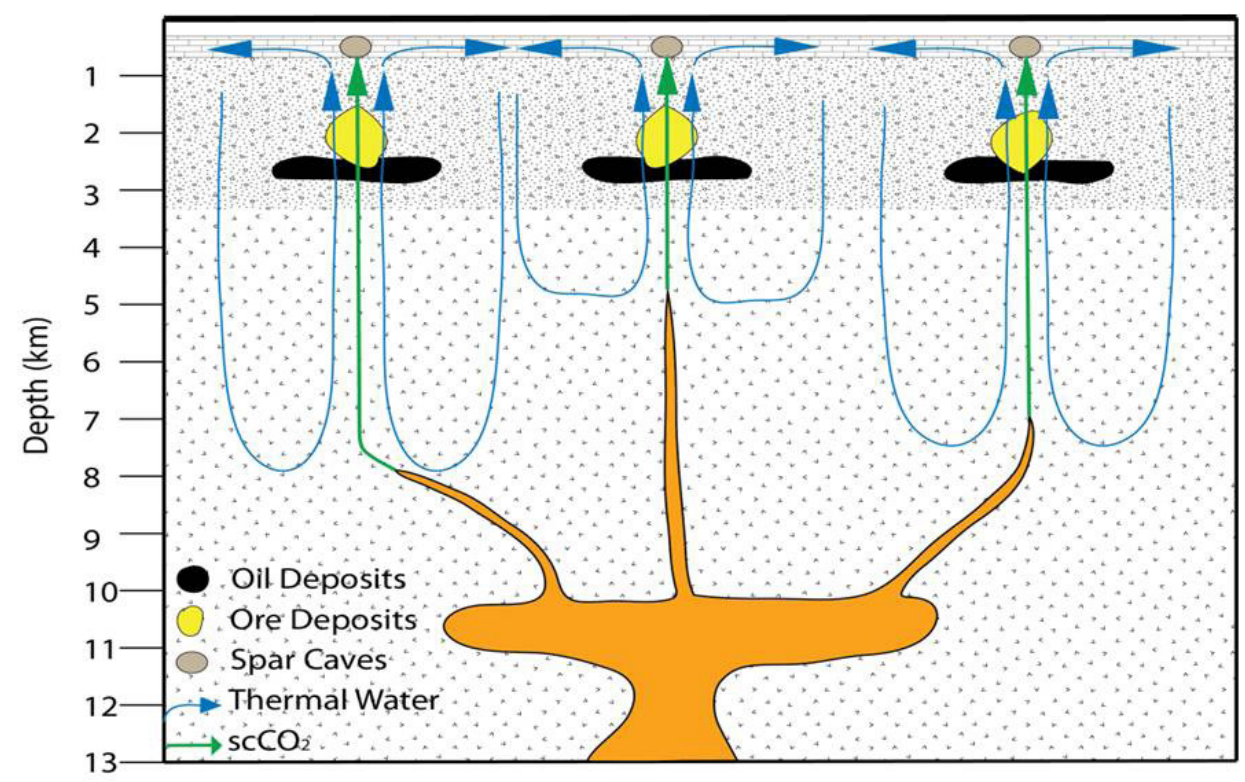

Fig. 5. Hydrothermal flow graphic. This graphic depicts the hydrothermal flow driven by magmatic processes. Heated groundwater scavenges and mobilizes metals from the host rock and then later deposits it at shallower depths as the temperature and pressure regimes change. As the fluids get closer to the surface, supercritical $\mathrm{CO}_{2}$ changes to sub-critical $\mathrm{CO}_{2}$ forming the small voids. The flow of groundwater near the surface removes the $\mathrm{CaCO}_{3}$ saturated water allowing further dissolution of the vugs. As the magmatic activity ceases and the flow of $\mathrm{scCO}_{2}$ wanes, the hydrologic flow changes and allows slightly $\mathrm{CaCO}_{3}$ saturated waters to remain in the area to precipitate the scalenohedral spar in the voids. 
thermal gradients, permeability of the surrounding rocks, tectonic faults, fractures, and in the case of the Guadalupe Mountains, cavernous porosity. These flow paths tend to change over time due to mineralization and diagenesis (Ingebritsen et al., 2006).

Epithermal economic mineral deposits exist due to mobilization and transport of metals from the surrounding country rock by groundwater heated through magmatism. Temperatures for this process range from 60 to $160^{\circ} \mathrm{C}$, but fall mostly between 110 and $130^{\circ} \mathrm{C}$ (Ridley, 2013). Metals in economic quantities are deposited in response to changes in temperature, pressure, redox state, or ground water mixing (Ingebritsen et al., 2006). We interpret that this happened beneath the horizon in which the spar caves are formed, at depths between 10 and $1 \mathrm{~km}$ as shown in Fig. 5 and 6 and suggested by Ingebritsen et al. (2006).

Known minerals in the Guadalupe Mountains include: iron oxides, copper, sulfur, and fluorite (Hill, 1990, 1996; Polyak \& Provencio, 2001), all of which can be deposited hydrothermally (Hill, 1996). Other studies show that Mississippi Valley-type (MVT) deposits form at shallow depth $(<800 \mathrm{~m})$ and moderate temperatures $\left(83\right.$ to $101^{\circ} \mathrm{C}$, (Ingebritsen et al., 2006). While MVT deposits in the United States are thought to occur from regional scale hydrologic flow and transport of metals over long distances, "Irish" MVTs, are shallow deposits associated with local volcanism and are good analogs for processes that may have occurred in the Guadalupe Mountains (Ingebritsen et al., 2006).

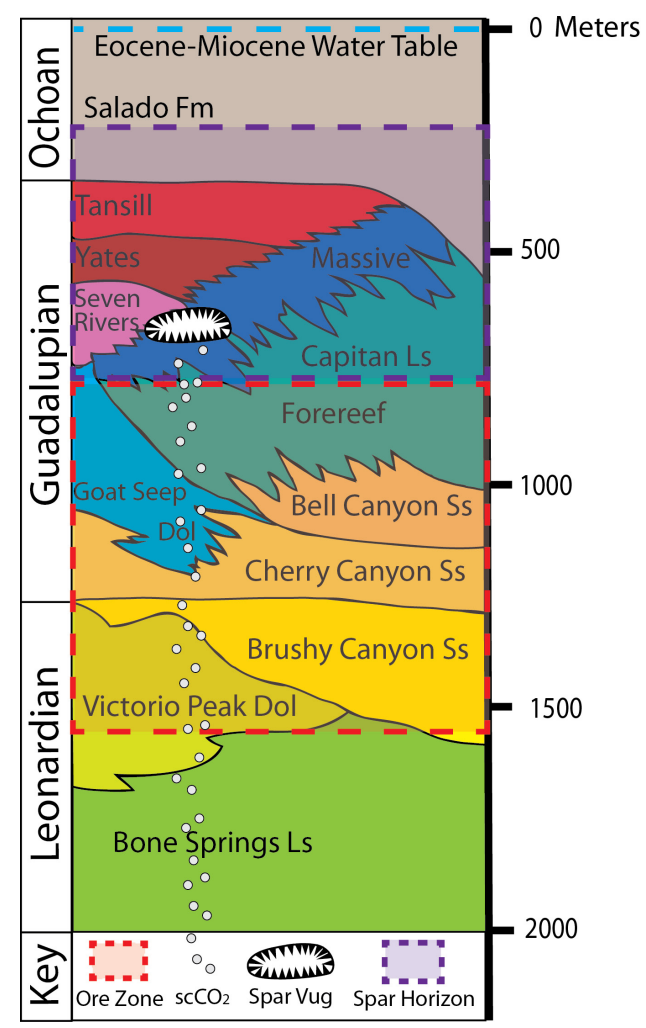

Fig. 6. Eocene-Miocene water table in the Ochoan Salado formation, which has subsequently been stripped from the Guadalupe Mountains during uplift. Spar horizon is $500 \pm 250$ meters below the water table, the ore zone extends to depth below the spar horizon. This stratigraphic section is based on the stratigraphy of the Capitan Reef near Carlsbad Caverns National Park, NM. Modified from King (1948) and Decker et al. (2018).
Based on the correlation of spar growth to known thermal events (Fig. 4), and ${ }^{87} \mathrm{Sr} /{ }^{86} \mathrm{Sr}$ and $\delta^{13} \mathrm{C}$ values of the $\mathrm{CaCO}_{3}$ (Decker et al., 2018; Fig. 7), it is evident that the provenance of the $\mathrm{CO}_{2}$ that formed the spar caves and cave spar was magmatic rather than soil derived. Because spar cave speleogenetic events are tied to magmatic activity and are therefore hydrothermal, the maturation of hydrocarbons and the deposition of ore deposits can be related to $\mathrm{scCO}_{2}$ speleogenesis more quantitatively. For example, in the maturation of petroleum source rocks, the 'oil window' is temperature dependent. Oil is generated and transported at temperatures of 60 to $120^{\circ} \mathrm{C}$ (Gutierrez et al., 2008; Stafford et al., 2008). At normal geothermal gradients, this takes place at 2-4 $\mathrm{km}$ depth. However, at geothermal gradients of 50 to $70^{\circ} \mathrm{C} / \mathrm{km}$, this can take place at $1-2 \mathrm{~km}$ depth. This may help explain the shallow, gas-rich hydrocarbon deposits in the western Delaware Basin. These episodes of magmatic activity are interpreted to be partially responsible for the driving force behind the maturation of hydrocarbon source rocks and also for ore deposition. Hill (1996) states that if a modernday geothermal gradient of $20^{\circ} \mathrm{C} / \mathrm{km}$ is assumed the depths required for the temperature to be high enough to begin cracking the hydrocarbons is deeper than the petroleum source rocks were buried. A much higher temperature gradient must have existed during the time of petroleum maturation $\left(50\right.$ to $70^{\circ} \mathrm{C} /$ $\mathrm{km})$. We assume that the magmatic events that drove the spar cave dissolution and spar formation may also have been responsible for the maturation and possible migration of the oils from source areas to the traps. Bitumen inclusions in spar formed during the ignimbrite flare-up support this conclusion (Fig. 8).

Elemental sulfur was first reported in Cottonwood Cave in the Guadalupe Mountains by Davis (1980), and in Carlsbad Cavern and Lechuguilla Cave by Hill (1995, 1996). These deposits show that sulfuric acid speleogenesis can form elemental sulfur deposits. The large economic deposits in the Delaware Basin also form from oxidation of $\mathrm{H}_{2} \mathrm{~S}$ (Barker et al., 1979; Hill, 1996) and are found in areas where hydrothermally driven fluids ascend from depth, such as the long graben-boundary faults in the Castile gypsum (Hill, 1996; Kirkland, 2014). Magmatic activity provides heat and energy for oil maturation and biogenic activity, giving rise to $\mathrm{H}_{2} \mathrm{~S}$ which interacts with oxygenated groundwater to form sulfur deposits. Some of this $\mathrm{H}_{2} \mathrm{~S}$ migrated up-dip to the Capitan reef and interacted with the oxygenated meteoric groundwater to form large sulfuric acid caves. It is likely that magmatic/tectonic events related to spar cave speleogenesis also play an important role in sulfuric acid cave speleogenesis (Lueth et al., 2004), and that large basinal deposits of elemental sulfur are related to magmatically-driven thermal pulses.

Small MVT ore deposits exist in the Guadalupe Mountains and Delaware Basin (Hill, 1996). Gossans are oxide-rich deposits typically related to hydrothermal springs and heavily enriched in iron, manganese, zinc, silver, and copper (Fig. 1). A wellknown gossan in the Guadalupe Mountains is the 


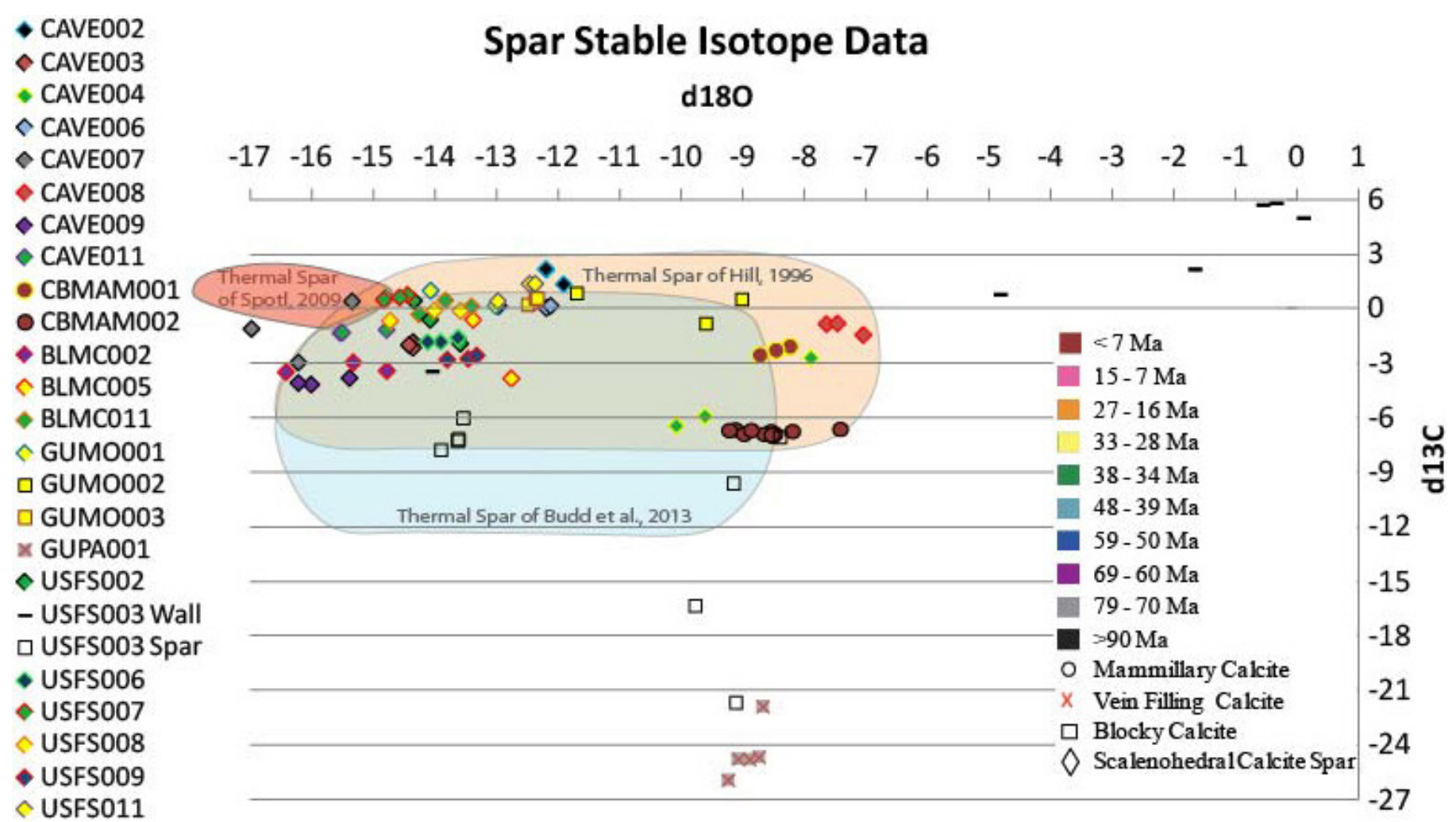

Fig. 7. Stable isotope data from scalenohedral spar formed in the Guadalupe Mountains. After Decker et al. (2018). Thermal fields: Hill (1996), Spötl (2009), and Budd et al. (2013) (The Spötl data is new for this figure).

Queen of the Guadalupes Mine, an oxide deposit above a cave which is known to contain molybdenum, lead, zinc (Hill, 1996), and trace amounts of barium, copper, and iron (Thompson, 1983). MVT deposits typically form between 83 to $101^{\circ} \mathrm{C}$ (Ridley, 2013), which corresponds to a depth of approximately 3 to 4 $\mathrm{km}$ for a typical geothermal gradient. However, several lines of research show that the area was likely never buried more than 1 to $1.5 \mathrm{~km}$, which suggests that the geothermal gradient was higher when these ores were emplaced. Spar caves and cave spar are formed by degassing thermal waters that derive their heat and $\mathrm{CO}_{2}$ from magma bodies, so it follows that MVT deposits could form at shallower depths, and there may be an association between spar cave density and epithermal ore deposits such as copper, silver, gold, and molybdenum at greater depth that were precipitated from rising hydrothermal plumes (Brown
\& Simmons, 2003; Simmons \& Brown, 2006). In areas such as the Guadalupe Mountains these spar caves can be used to locate areas of fossil hydrothermal systems that could lead to ore bodies of economic value.

The Border Fault zone vein spar in Guadalupe Pass indicates that the faults responsible for tilting of the Guadalupe tectonic block were active as early as 16.1 $\pm 0.4 \mathrm{Ma}$. This pushes back the timing of the uplift from a minimum of $12 \mathrm{Ma}$ (Polyak et al., 1998) to at least $16 \mathrm{Ma}$. The youngest cave spar dated thus far on the western end of the Guadalupe Mountains tectonic block is $28 \mathrm{Ma}$ (sample GUMO-00549-002). A previous study (Decker et al., 2018) indicates that the uplift of this tectonic block, the rise of the cave-forming strata above the water table, occurred between 28 and 16 $\mathrm{Ma}$ and probably marks the end of major hydrocarbon maturation and ore deposition in the region.

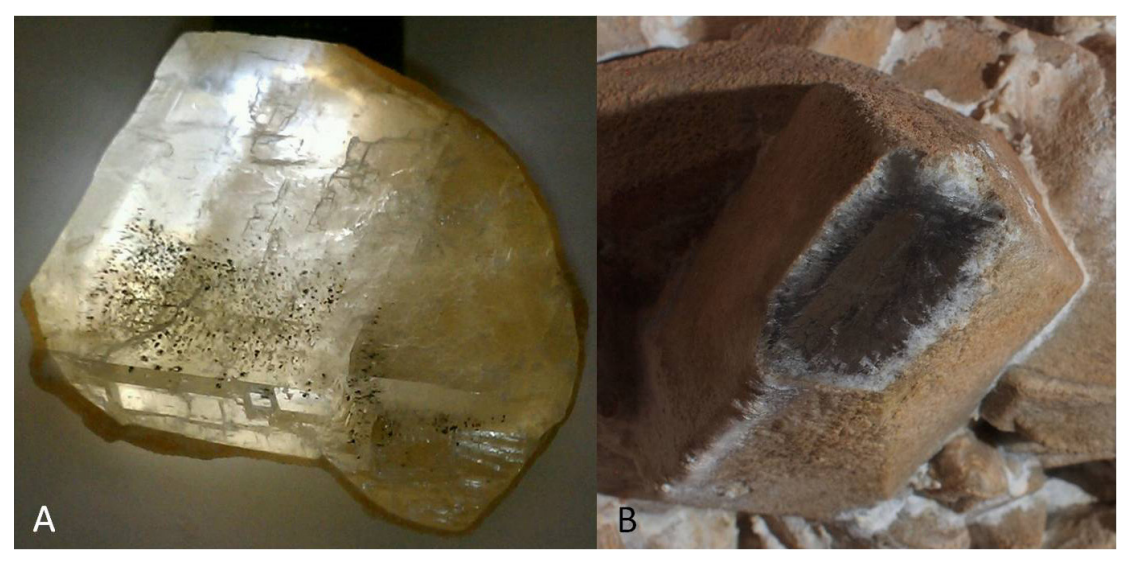

Fig. 8. Cave spar samples from the Guadalupe Mountains contain numerous bitumen inclusions. These two samples come from widely separated locations. The sample on the left $(A)$ is from cave BLM-NM-060-030 and is $29.8 \pm 1.2 \mathrm{Ma}$. The sample on the right $(B)$ is from cave CAVE-C-10 $20 \mathrm{~km}$ to the southwest and is $36.1 \pm 2.1 \mathrm{Ma}$ (Photo: Dave Decker).

\section{CONCLUSION}

Euhedral calcite spar that lines spar caves can be used to interpret the tectonic and geothermal history of the Guadalupe Mountains and should be applicable to other regions. This type of cave spar only precipitates at shallow crustal depths and within limited temperature and pressure ranges resulting in a spar horizon. The spar horizon can then be used as a constraining factor on the history of landscape development since there is a delicate balance between uplift and location of the water table in a karst environment like the Guadalupe Mountains. Since hydrothermal deposits 
disappear from the landscape quickly, having a proxy for their locations can help determine past histories of a region including possible volcanic activity and ore deposition. Dating of cave spar and determination of the temperature of precipitation can further constrain uplift rates and help to determine the age and location of economic epithermal ore deposits and the timing of petroleum maturation. In this paper, we have linked magmatic intrusion and associated hydrothermal activity to the timing of spar cave speleogenesis involving precipitation of cave spar, the timing of petroleum maturation and migration, and the origin of ore deposits.

\section{ACKNOWLEDGEMENTS}

Funding for this research has been provided by the National Science Foundation (NSF; EAR-0214294 \& EAR-0518602), Cave Research Foundation (CRF), National Speleological Society (NSS), Cleveland Grotto, University of New Mexico Alumni Association and the New Mexico Geological Society (NMGS). We'd also like to thank Carlsbad Caverns National Park (Dale Pate, Stan Allison, and Shawn Thomas), Guadalupe Mountains National Park (Jonena Hearst), Bureau of Land Management, Carlsbad Field Office (Jim Goodbar and Aaron Stockton) and U.S. Forest Service, Guadalupe District (Jason Walz) for their help and support during our field work and finally, our field assistants, Garrett Jorgensen and Dr. Michael Queen. Thank you to the reviewers for the input and guidance provided, which has improved this article.

\section{REFERENCES}

Austin G.S., 1978 - Geology and mineral deposits of Ochoan rocks in Delaware Basin and adjacent areas. Socorro, NM. New Mexico Bureau of Mines and Mineral Resources, $88 \mathrm{p}$.

Barker C.E. \& Pawlewicz M.J., 1987 - The effects of igneous intrusions and higher heatflow on the thermal maturity of Leonardian and younger rocks, western Delaware Basin, Texas. In: Cromwell D.W. \& Mazullo L. (Eds.), Glass Mountains. Society of Economic Paleontologists and Mineralogists, p. 69-83.

Barker J.M., Cochran D.E. \& Semrad R., 1979 - Economic Geology of the Mishraq Native Sulfur Deposit, Northern Iraq. Economic Geology, 74: 484-495. https://doi.org/10.2113/gsecongeo.74.2.484

Barnes V.E., 1983 - Geologic atlas of Texas, Van Horn and El Paso sheet. Scale 1:250,000, Texas Bureau of Geology.

Brown K.L. \& Simmons S.F., 2003 - Precious metals in high-temperature geothermal systems in New Zealand. Geothermics, 32 (4-6): 619-625.

https://doi.org/10.1016/S0375-6505(03)00049-X

Budd D.A., Frost E.L., Huntington K.W. \& Allwardt P.E., 2013 - Syndepostional deformation features in high-relief carbonate platforms: Long-lived conduits for diagenetic fluids. Journal of Sedimentary Research, 82: $12-36$.

https://doi.org/10.2110/jsr.2013.3

Davis D.G., 1980 - Cave development in the Guadalupe Mountains - A critical review of recent hypotheses. National Speleological Society Bulletin, 42: 42-48.
Decker D.D., Polyak V.J. \& Asmerom Y., 2016 - Depth and timing of calcite spar and 'spar cave' genesis: Implications for landscape evolution studies. In: Feinberg J.M., Gao Y. \& Alexander E.C., Jr. (Eds.), Caves and karst across time. GSA Special Publication, 516: 103-111.

https://doi.org/10.1130/2015.2516(08)

Decker D.D., Polyak V.J., Asmerom Y. \& Lachniet M.S., 2018 - U-Pb dating of cave spar: A new shallow crust landscape evolution tool. Tectonics, 37 (1): 208-223. https://doi.org/10.1002/2017TC004675

Dublyansky Y.V., 1995 - Speleogenetic history of the Hungarian hydrothermal karst. Environmental Geology, 25 (1): 24-35. https://doi.org/10.1007/BF01061827

Dublyansky Y.V., 2000 - Dissolution of carbonates by geothermal waters. In: Klimchouk A.B., Ford D.C., Palmer A.N. \& Dreybrodt W. (Eds.), Speleogenesis Evolution of karst aquifers. Huntsville, AL, National Speleological Society, p. 158-159.

DuChene H.R. \& Cunningham K.L., 2006 - Tectonic influences on speleogenesis in the Guadalupe Mountains, New Mexico and Texas. New Mexico Geological Society Guidebook, $57^{\text {th }}$ Field Conference, Caves and Karst of Southeastern New Mexico. Soccorro, NM, New Mexico Geological Society, p. 211-218.

DuChene H.R. \& Martinez R., 2000 - Post-speleogenetic erosion and its effect on caves in the Guadalupe Mountains, New Mexico and West Texas. Journal of Cave and Karst Studies, 62 (2): 75-79. http://ww.caves.org/pub/journal/PDF/V62/v62n2DuChene-Martinez.pdf

DuChene H.R., Palmer A.N., Palmer M.V., Queen J.M., Polyak V.J., Decker D.D., Hill C.A., Spilde M., Burger P.A., Kirkland D.W. \& Boston P.J., 2017 - Hypogene speleogenesis in the Guadalupe Mountains, New Mexico and Texas, USA. In: Klimchouk A.B., Palmer A.N., De Waele J., Auler A.S. \& Audra P. (Eds.), Hypogene karst regions and caves of the world. Springer, Cham, p. 511-530.

https://doi.org/10.1007/978-3-319-53348-3_31

Eaton G.P., 1986 - Tectonic redefinition of the Southern Rocky Mountains. Tectonophysics, 132: 163-193. https://doi.org/10.1016/0040-1951(86)90031-4

Garber R.A., Grover G.A. \& Harris P.M., 1989 - Geology of the Capitan Shelf Margin - subsurface data from the northern Delaware Basin. In: Harris P.M. \& Grover G.A. (Eds.), Subsurface and outcrop examination of the Capitan shelf margin, northern Delaware Basin, Volume 13. San Antonio, TX, Society of Economic Paleontology and Mineralogy, p. 3-269.

Gary M.O., Sharp J.M. \& Havens R.S., 2002 - Identifying the connection between volcanic activity and hypogenic karst in a hydrothermal phreatic cave system. Geo2, 29 (3-4): 1-14.

Gregory K.M. \& Chase C.G., 1992 - Tectonic significance of paleobotanically estimated climate and altitude of the late Eocene erosion surface, Colorado. Geology, 20: 581-585.

https://doi.org/10.1130/0091-7613(1992)020\%3C05 81:TSOPEC\%3E2.3.CO;2

Gutierrez F., Cooper A.H. \& Johnson K.S., 2008 Identification, prediction, and mitigation of sinkhole hazards in evaporite karst areas. Environmental Geology, 53: 1007-1022.

https://doi.org/10.1007/s00254-007-0728-4

Hayes P.T., 1964 - Geology of the Guadalupe Mountains, New Mexico U.S. Government Printing Office, Washington D.C., U.S. Department of the Interior, Geological Survey Professional Paper 446: 69 p. 
Hill C.A., 1987 - Geology of Carlsbad Cavern and other caves in the Guadalupe Mountains, New Mexico and Texas. Socorro, NM, New Mexico Bureau of Mines and Mineral Resources, 117: 150 p.

https://geoinfo.nmt.edu/publications/monographs/ bulletins/downloads/117/Bulletin117.pdf

Hill C.A., 1990 - Sulfuric acid speleogenesis of Carlsbad Cavern and its relationship to hydrocarbons, Delaware Basin, New Mexico and Texas. AAPG Bulletin, 74 (11): 1685-1694.

http://archives.datapages.com/data/bulletns/ 1990-91/data/pg/0074/0011/0000/1685.htm

Hill C.A., 1995 - Sulfur redox reactions: Hydrocarbons, native sulfur, Mississippi Valley-type deposits, and sulfuric acid karst in the Delaware Basin, New Mexico and Texas. Environmental Geology, 25: 16-23. https://doi.org/10.1007/BF01061826

Hill C.A., 1996 - Geology of the Delaware Basin, Guadalupe, Apache and Glass Mountains, New Mexico and West Texas. Albuquerque, NM, Permian Basin Section - SEPM, 480 p.

Hill C.A., 2000 - Overview of the geologic history of cave development in the Guadalupe Mountains. Journal of Cave and Karst Studies, 62 (2): 60-71.

http://ww.caves.org/pub/journal/PDF/V62/v62n2Hill.pdf

Hills J.M., 1984 - Sedimentation, tectonism, and hydrocarbon generation in Delaware Basin, West Texas and Southeastern New Mexico. The American Association of Petroleum Geologists Bulletin, 68 (3): 250-267.

http://archives.datapages.com/data/bulletns/ 1984-85/data/pg/0068/0003/0250/0250.htm

Ingebritsen S., Sanford W. \& Neuzil C., 2006 Groundwater in geologic processes. Cambridge University Press, New York, 536 p.

Jagnow D.H., 1977 - Geologic factors influencing speleogenesis in the Capitan Reef complex, New Mexico and Texas. Unpublished MS Thesis, University of New Mexico, 197 p.

King P.B., 1948 - Geology of the Southern Guadalupe Mountains, Texas. Geological Survey Professional Paper, Washington D.C., United States Department of the Interior, 215: $183 \mathrm{p}$.

Kirkland D.W., 2014 - Role of hydrogen sulfide in the formation of cave and karst phenomena in the Guadalupe Mountains and Western Delaware Basin, New Mexico and Texas. Carlsbad, NM, National Cave and Karst Research Institute, NCKRI Special Paper 2: $77 \mathrm{p}$.

Loyd S.J., Dickson J.A.D., Scholle P.A. \& Tripati A.K., 2013 - Extensive uplift-related and non-fault-controlled spar precipitation in the Permian Capitan Formation. Sedimentary Geology, 298: 17-27.

https://doi.org/10.1016/j.sedgeo.2013.10.001

Lueth V.W., Rye R.O. \& Peters L., 2004 - "Sour gas" hydrothermal jarosite: ancient to modern acid-sulfate mineralization in the southern Rio Grande Rift. Chemical Geology, 215: 339-360.

https://doi.org/10.1016/j.chemgeo.2004.06.042

Lundberg J.L., Ford D.C. \& Hill C.A., 2000 - A preliminary $\mathrm{U}-\mathrm{Pb}$ date on cave spar, Big Canyon, Guadalupe Mountains, New Mexico, USA. Journal of Cave and Karst Studies, 62 (2): 144-148.

http://ww.caves.org/pub/journal/PDF/V62/v62n2Lundberg.pdf
McKnight C.L., 1986 - Descriptive geomorphology of the Guadalupe Mountains, South-Central New Mexico and West Texas. Baylor Geologic Studies Bulletin, 43: 27-28.

Meyer R.F., 1966 - Geology of the Pennsylvanian and Wolfcampian Rocks in Southeast New Mexico. Socorro, NM, New Mexico Bureau of Mines and Mineral Resources, Memoir 17: 123 p.

Mruk D.H., 1985 - Cementation and dolomitization of the Capitan Limestone (Permian), McKittrick Canyon, West Texas. Unpublished MS Thesis, University of Colorado, Boulder, 155 p.

Mruk D.H., 1989 - Diagenesis of the Capitan Limestone, Upper Permian, McKittrick Canyon, West Texas, Subsurface and Outcrop Examination of the Capitan Shelf Margin, Northern Delaware Basin. San Antonio, TX, SEPM, 13: 387- 73.

Palmer A.N. \& Palmer M.V., 2000 - Hydrochemical interpretations of cave patterns in the Guadalupe Mountains, New Mexico. Journal of Cave and Karst Studies, 62 (2): 91-108.

http://ww.caves.org/pub/journal/PDF/V62/v62n2Palmer.pdf

Pollack H.N., Hurter S.J. \& Johnson J.R., 1993 - Heat flow from the Earth's interior: Analysis of the global data set. Reviews of Geophysics, 31 (3): 267-280. https://doi.org/10.1029/93RG01249

Polyak V.J., 1992 - The Mineralogy, petrology and diagenesis of carbonate speleothems from caves in the Guadalupe Mountains, New Mexico. Unpublished MS Thesis, Texas Tech University, 165 p.

Polyak V.J., McIntosh W.C., Guven N. \& Provencio P., 1998 - Age and origin of Carlsbad Cavern and related caves from ${ }^{40} \mathrm{Ar} /{ }^{39} \mathrm{Ar}$ of alunite. Science, 279: 1919-1922. https://doi.org/10.1126/science.279.5358.1919

Polyak V.J. \& Provencio P., 2001 - By-product materials related to $\mathrm{H}_{2} \mathrm{~S}-\mathrm{H}_{2} \mathrm{SO}_{4}$ influenced speleogenesis of Carlsbad, Lechuguilla, and other Caves of the Guadalupe Mountains, New Mexico. Journal of Cave and Karst Studies, 63 (1): 23-32. http://ww.caves.org/pub/journal/PDF/V63/v63n1Polyak.pdf

Ridley J., 2013 - Ore deposit geology. Cambridge University Press, New York, 398 p.

https://doi.org/10.1017/CBO9781139135528

Simmons S.F. \& Brown K.L., 2006 - Gold in magmatic hydrothermal solutions and the rapid formation of a giant ore deposit. Science, 314: 288-291. https://doi.org/10.1126/science.1132866

Spötl C., Dublyansky Y., Meyer M. \& Mangini A., 2009 - Identifying low-temperature hydrothermal karst and paleowaters using stable isotopes: a case study from an alpine cave, Entrische, Kirche, Austria. International Journal of Earth Science, 98 (3): 665-676. https://doi.org/10.1007/s00531-007-0263-2

Stafford K.W., Rosales-Lagarde L. \& Boston P.J., 2008 - Castile evaporite karst potential map of the Gypsum Plain, Eddy County, New Mexico and Culberson County, Texas: A GIS methodological comparison. Journal of Cave and Karst Studies, 70 (1): 35-46. http://ww.caves.org/pub/journal/PDF//v70/cave70-01-35.pdf

Thompson J.R., 1983 - Mineral investigation of the Guadalupe Escarpment wilderness study area, Eddy County, New Mexico. U.S. Bureau of Mines and Mineral Resources Lands Assessment Report U.S. Bureau of Mines and Mineral Resources, 41-83: p. 16. 